\title{
ANALISIS YURIDIS TENTANG PENDIRIAN YAYASAN PENDIDIKAN SETELAH BERLAKUNYA UNDANG-UNDANG NOMOR 28 TAHUN 2004 TENTANG PERUBAHAN ATAS UNDANG-UNDANG NOMOR 16 TAHUN 2001 TENTANG YAYASAN
}

\author{
Desi Handayani \\ Evi Haryani \\ Ida Ayu Putu Anggie S \\ STMIK Pringsewu \\ desihandayaniumar@gmail.com
}

\begin{abstract}
Abstrak
Jenis penelitian ini adalah normatif bersifat deskriptif dengan pendekatan undang-undang. Data yang digunakan adalah data sekunder yang terdiri dari: Pertama, bahan hukum primer,dan bahan hukum sekunder. Dari hasil penelitian dapat disimpulkan Persepsi dan pengetahuan masyarakat (pengurus yayasan) atas keberadaan Undangundang Yayasan belum berbanding lurus dengan pengetahuannya atas substansi yang dirubah. UU Nomor 28 Tahun 2004 Tentang Perubahan Atas UU Nomor 16 Tahun 2001 tentang yayasan menyatakan bahwa setiap yayasan adalah sebuah badan hukum yang mengikuti prosedur dan mekanisme yang sudah diatur dalam undang-undang dimaksud. Salah satunya adalah mewajibkan setiap yayasan untuk mendaftar dan menyesuaikan anggaran dasarnya sekaligus mendapatkan pengesahan dari Kementerian Hukum dan HAM. Sehingga kapasitasnya dapat dianggap sebagai badan hukum dan sebagai salah satu bentuk pertanggung jawaban terhadap publik. Konsekuensinya adalah setiap yayasan pendidikan dan atau melalui notaris yang membuat akta pendiriannya harus menyesuaikan anggaran dasarnya sesuai dengan ketentuan UU Yayasan. Hal inilah tentunya yang harus dipahami oleh setiap satuan penyelengga pendidikan.
\end{abstract}

Kata kunci: Undang-undang, Yayasan Pendidikan, Yuridis

\section{A. Pendahuluan}

Negara-negara maju pendidikan merupakan salah satu faktor yang sangat diperhatikan, mulai dari pendidikan dasar, menengah sampai dengan pendidikan tinggi. Baik buruknya pendidikan diyakini memiliki nilai pengaruh terhadap kualitas hidup sebuah negara. Oleh karenanya semua stakeholders (pemangku kepentingan) memberikan perhatian yang sungguh- 
sungguh terhadap dunia pendidikan. Dengan perkembangan zaman di dunia pendidikan, sangat perlu merubah pola pikir pendidik dari pola pikir yang awam dan kaku (konvensional) menjadi lebih moderat untuk kemajuan pendidikan di Indonesia. Menyikapi hal tersebut pakar-pakar pendidikan mengkritisi dengan cara mengungkapkan beberapa pengertian dasar dan terminologi pendidikan untuk mencapai tujuan pendidikan yang sesungguhnya. ${ }^{1}$ Dalam memelihara dan memberi latihan diperlukan adanya ajaran, tuntunan dari pimpinan mengenai akhlak dan kecerdasan pikiran. Pendidikan merupakan hal pokok untuk memajukan sebuah bangsa, mengingat Indonesia masih merupakan negara berkembang sangat penting untuk memajukan pendidikan baik itu pendidikan formal dan non formal, pendidikan adalah pintu awal untuk membuka kesulitan-kesulitan dari masalah ekonomi maupun masalah lainnya. Pentingnya pendidikan, maka pemerintah wajib untuk memperhatikan instrumen hukum yang berlaku agar para pendiri pendidikan di bidang yayasan dapat menjalankan pendidikan sesuai dengan undang-undang yang berlaku serta tidak melanggar aturan hukum.

Badan hukum Yayasan adalah badan hukum yang banyak dipergunakan oleh masyarakat di dalam menyelenggarakan, termasuk pendidikan. Konstitusi Indonesia yang tertuang didalam Undang - Undang Dasar 1945 dalam pembukaan pada alinea keempat menyatakan: "Kemudian dari pada itu untuk membentuk suatu pemerintahan Negara Indonesia yang melindungi segenap bangsa Indonesia dan tumpah darah Indonesia dan untuk memajukan kesejahteraan umum, mencerdaskan kehidupan bangsa", ${ }^{2}$. Alinea ke empat UUD 1945 jelas menerangkan Pemerintah harus memberikan perhatian lebih terkait mencerdaskan anak bangsa.

Di Indonesia praktiknya Yayasan merupakan suatu lembaga yang pokok fungsinya berperan sebagai wujud kepedulian sosial masyarakat, karena program kerja dan kegiatannya bergerak dibidang sosial kemasyarakatan dan kemanusiaan. Yayasan sebagai suatu lembaga dikelola atau terdiri dari pribadi-pribadi atau kelompok masyarakat umum maupun masyarakat kolegial, yang memiliki kesamaan visi dan akumulasi dari rasa saling peduli terhadap sesama dalam suatu wadah untuk menjalankan misi kepedulian sosial. Di Indonesia sudah sejak dulu dikenal adanya beberapa bentuk Yayasan yang keseluruhan dalam praktek diakui sebagai subyek hukum. Tujuan ini umumnya bukan untuk meraih keuntungan. Dalam Undang Undang Nomor 16 Tahun 2001 tentang Yayasan yang selanjutnya diubah

1 . Taufik H. Simatupang, Kesadaran badan Hukum Yayasan Pendidikandi Indonesia (Persepsi dan Kesadaran Masyarakat), 2016, Jurnal Penelitian Hukum De Jure Volume 16 Nomor 3, September 2016, Hlm. 278.

2 Undang Undang Dasar 1945 
dengan Undang - Undang Nomor 28 Tahun 2004 pasal 1 ayat (1) dengan tegas menyebutkan bahwa "Yayasan adalah badan hukum yang terdiri atas kekayaan yang dipisahkan dan diperuntukan untuk mencapai tujuan tertentu di bidang sosial, keagamaan, dan kemanusiaan, yang tidak mempunyai anggota. ${ }^{3}$ dengan ini Penelitian tentang "Analisis Yuridis Tentang Pendirian Yayasan Pendidikan Setelah Berlakunya Undang-Undang Nomor. 28 Tahun 2004 Tentang Perubahan atas Undang-Undang Nomor 16 Tahun 2001 tentang Yayasan" menjadi penting di sebabkan oleh dua hal : Pertama, bahwa mendirikan Yayasan adalah untuk mengelola kegiatan yang bersifat komersil yang berkedok Yayasan walau dalam usahanya telah berubah menjadi kerajaan bisnis yang bergerak dalam bidang pendidikan. Agar kegiatan usaha yang dilakukannya tidak terkena pajak yang berkaitan dengan usaha tersebut, maka seseorang membentuk yayasan. Mereka beranggapan bahwa Yayasan jika menjalankan kegiatan usaha, akan mendapatkan pembebasan pajak.

Kedua, bahwa tidak semua orang mendirikan yayasan pendidikan dengan tujuan beramal, melainkan juga tujuan utama adalah untuk memperkaya diri para pendiri, pengurus, dan pengawas. Yayasan sesungguhnya merupakan suatu lembaga yang pokok fungsinya berperan sebagai wujud kepedulian sosial masyarakat. Lahirnya yayasan di bidang pendidikan ini sesungguhnya adalah wujud dari kepedulian sosial masyarakat, karena yayasan di bidang pendidikan bertujuan untuk mencerdaskan anak bangsa Indonesia, yayasan pendidikan sangat berpengaruh untuk kemajuan perekonomian internal maupun eksternal, semakin banyak yang mendirikan yayasan pendidikan akan menstimulasikan masyarakat pentingnya pendidikan sehingga memberikan keuntungan satu sama lain, yayasan pendidikan ini juga merupakan kategori bisnis jangka panjang, dengan begitu tidak dapat dipungkiri bahwa banyak pengusaha yang berlomba-lomba mendirikan usaha di bidang pendidikan, tetapi tidak sedikit yang tidak mengikuti prosedur pendirian yang dibenarkan oleh Undang-undang. Disebabkan latar belakang inilah penulis ingin menanalisis bagaimana mendirikan yayasan di bidang pendidikan sesuai dengan aturan hukum yang berlaku.

\section{B. Metode Penelitian}

Metode penelitian Jenis artikel ini adalah normatif bersifat Dreskriptif dengan pendekatan undang-undang. Data yang digunakan adalah data sekunder yang terdiri dari: Pertama, bahan hukum primer diantaranya UU No. 16 Tahun 2001 dan UU yayasan No. 28 Tahun 2004; Kedua, bahan hukum sekunder yang digunakan dalam penelitian hukum ini meliputi buku-

3. Undang - Undang Nomor 28 Tahun 2004 Atas Perubahan Undang Undang Nomor 11 Tahun 2001 Tentang Yayasan 
buku, kamus-kamus hukum, jurnal-jurnal hukum, hasil karya ilmiah dan penelitian-penelitian yang relevan atau terkait dengan penelitian ini termasuk diantaranya skripsi, tesis, disertasi, majalah, dan artikel hukum. Artikel ini menggunakan teknik pengumpulan bahan dengan cara studi kepustakaan atau studi dokumen (library research) dengan membaca, mengkaji dari buku, peraturan perundangundangan, tulisan, dan publikasi ilmiah yang berkaitan dengan pengawasan pengelolaan yayasan. Analisis bahan hukum yang digunakan penulis dalam artikel ini menggunakan metode deduksi.

\section{Pembahasan}

Yayasan adalah badan hukum yang diperuntukan untuk mencapai tujuan tertentu dibidang sosial, keagamaan, dan kemanusiaan. Ketiga tujuan yayasan ini dapat dikategorikan lapangan gerak yayasan seperti dalam bidang kesejahtraan sosial, pendidikan, kebudayaan, kesehatan, dan bidang-bidang lainnya yang tidak bertentangan dengan undang-undang. Untuk mencapai maksud dan tujuannya yayasan dapat melakukan kegiatan usaha. Kegiatan usaha yang dimaksud dapat dilakukan sesuai ketentuan yang terurai di dalam Pasal 3 ayat (1) Undang-Undang Yayasan yang menyatakan bahwa yayasan dapat melakukan kegiatan usaha untuk menunjang pencapaian maksud dan tujuannya dengan cara mendirikan badan usaha dan/atau ikut serta dalam badan usaha, dalam penjelasan Pasal 3 Ayat (1) yang tercantum dalam Undang-Undang Yayasan menyatakan ketentuan dalam ayat ini dimaksudkan untuk menegaskan bahwa yayasan tidak dibenarkan sebagai wadah usaha dan tidak dapat melakukan kegiatan usaha secara langsung tetapi harus melalui badan usaha yang didirikannya atau melalui badan usaha lain dimana yayasan menyertakan kekayaannya. Bagi yayasan dimungkinkan untuk menjalankan badan usaha agar mendapatkan keuntungan dengan cara :

1. Yayasan dapat mendirikan dan/atau turut serta dalam badan usaha yang kegiatannya sesuai sesuai dengan maksud dan tujuan yayasan yakni bersifat sosial, keagamaan, dan kemanusiaan.

2. Yayasan dapat melakukan penyertaan dalam berbagai bentuk usaha dengan menanamkan modalnya pada badan usaha lain baik dalam bentuk Perseroan Terbatas, dengan ketentuan usaha tersebut tidak bertentangan dengan keteriban umum, kesusilaan, dan/atau peraturan perundangundangan yang berlaku. Penyertaan modal yayasan yang bersifat prospektif dalam suatu badan usaha jumlahnya tidak boleh melebihi $25 \%$ dari seluruh nilai kekayaan yayasan.

Dari uraian mengenai usaha-usaha yayasan, terlihat bahwa saat ini dalam praktiknya sudah banyak yayasan yang tidak murni sebagai non profit oriented, tetapi sudah mengarah pada tujuan komersial. Bahkan beberapa lembaga pendidikan yang berlabel yayasan.

Yayasan memiliki berbagai macam bentuk salah satunya adalah yayasan pendidikan. Dalam mendirikan yayasan pendidikan, pada umumnya sama 
dengan mendirikan yayasan pada bidang lain. Maka dari itu karena terbitnya perundangan- undangan yang mengharuskan yayasan pendidikan berbadan hukum dan terdaftar inilah yang perlu diperhatikan dalam proses pendirian yayasan pendidikan itu sendiri. Karena, tidak adanya akta pendirian pada yayasan pendidikan berdampak pada tidak akan mendapatkan Bantuan Operasional Sekolah dan bantuan dalam bentuk lainya dari pemerintah, maka dari itu perlu diperhatikan langkah atau syarat yang harus dipenuhi dalam syarat pendirian yayasan di bidang pendidikan.

Undang-undang Yayasan Nomor 28 Tahun 2004 menegaskan bahwa yayasan adalah suatu badan hukum yang mempunyai maksud dan tujuan bersifat sosial, keagamaan dan kemanusiaan didirikan dengan memperhatikan persyaratan formal yang ditentukan dalam Undang-undang, dan akan dijadikan sebagai dasar hukum yang kuat dalam mengatur berjalannya suatu yayasan. Perubahan pokok-pokok undang-undang No. 28 Tahun 2004 dari yang sebelumnya undang-undang No. 16 Tahun 2001 adalah:

\begin{tabular}{|c|l|l|}
\hline NO & \multicolumn{1}{|c|}{ SEBELUM No. 16 Tahun 2001 } & \multicolumn{1}{|c|}{$\begin{array}{c}\text { SESUDAH } \\
\text { UU No. 28 Tahun 2004 }\end{array}$} \\
\hline 1 & $\begin{array}{l}\text { Pendirian yayasan tidak perlu } \\
\text { pengesahan dari pemerintah }\end{array}$ & $\begin{array}{l}\text { Pendirian yayasan diperlukan pengesahan } \\
\text { dari pemerintah }\end{array}$ \\
\hline 2 & $\begin{array}{l}\text { Belum ada pengesahan dari menteri } \\
\text { kehakiman }\end{array}$ & Ada pengesahan dari menteri kehakiman \\
\hline 3 & $\begin{array}{l}\text { Organ yayasan dibolehkan merangkap } \\
\text { jabatan }\end{array}$ & $\begin{array}{l}\text { Organ yayasan tidak diperbolehkan } \\
\text { merangkap jabatan }\end{array}$ \\
\hline 4 & $\begin{array}{l}\text { Tidak ada batasan terhadap masa kerja } \\
\text { organ yayasan }\end{array}$ & $\begin{array}{l}\text { Ada batasan terhadap masa kerja organ } \\
\text { yayasan }\end{array}$ \\
\hline 5 & Nama yayasan diperbolehkan sama & Nama yayasan tidak diperbolehkan sama \\
\hline 6 & Yayasan tidak bisa dipailitkan & Yayasan bisa dipailitkan \\
\hline
\end{tabular}

Undang-undang Yayasan pada prinsipnya menghendaki yayasan bersifat terbuka dan pengelolaannya bersifat profesional. Dengan adanya Undangundang Yayasan memberikan kabar baik bagi masyarakat, karena sudah ada kaidah hukum yang menjadi pegangan bagi mereka yang berkecimpung dalam yayasan dan sebagai pegangan bagi masyarakat pada umumnya. Masyarakat dapat melihat bagaimana kehidupan yayasan di Indonesia setelah berlakunya Undang-undang Yayasan. Mengenai yayasan dikehendaki bersifat terbuka, dapat dilihat dari sejumlah aturan mainnya dalam UU Nomor 16 Tahun 2001 jo UU Nomor 28 Tahun 2004, antara lain:

1. Cara mencari dana Yayasan tidak dapat menjalankan usaha secara langsung karena yayasan kedudukannya bukan sebagai badan usaha atau perusahaan, dan yayasan tidak sebagai lembaga yang tujuannya mencari keuntungan. Namun yayasan dapat mencari dana untuk kepentingan yayasan, dengan jalan mendirikan badan usaha. Disini yayasan hanya mendirikan badan usaha, dan kedudukannya juga semata-mata sebagai pendiri usaha. Yayasan selaku pendiri, tidak dapat 
mengelola badan usaha itu. Pasal 7 ayat (3) melarang dengan tegas kepada anggota Pembina, pengurus dan pengawas yayasan merangkap menjadi anggot direksi (pengurus) atau komisaris (pengawas) badan usaha yang didirikan yayasan;

2. Cara mengelola kekayaan Kekayaan yayasan yang berasal dari kegiatan usaha maupun dari sumbangan pihak ketiga, merupakan milik yayasan dan sesuai dengan Pasal 3 ayat (2) dan Pasal 5 ayat (1) tidak boleh dibagikan atau dialihkan kepada Pembina, pengurus maupun pengawas yayasan. Aturan main yang demikian, tuajuannya untuk menghidari agar sebuah yayasan jangan sampai disalahgunakan untuk mencari dana atau keuntungan bagi para personal organ yayasan. Juga untuk melindungi yayasan tetap dapat mencapai tujuan yang dicita-citakan;

3. Akta pendirian diumumkan Setiap yayasan diharuskan mempunyai akta pendirian dan akta tersebut disahkan oleh Menteri Hukum dan HAM, kemudian diumumkan dalam Berita Negara RI (Pasal 24). Dengan pengumuman tersebut masyarakat telah dianggap mengetahui setiap ada yayasan yang baru didirikan. Dengan mengajukan permohonan pengesahan kepada Menteri dan mengumumkan dalam Bertia Negara, maka perbuatan tersebut dapat dikatakan perbuatan hukum sekaligus sikap keterbukaan dari sebuah yayasan, karena angaran dasarnya diketahui oleh pemerintah dan keberadaannya diakui oleh Negara dan masyarakat.;

4. Organ yayasan Setiap yayasan wajib memiliki alat perlengkapan yang berupa Pembina, pengurus dan pengawas. Kemudian setiap alat perlengkapan dapat memiliki lebih dari seorang anggota. Untuk mengisi atau mengangkat anggota organ yayasan tersebut, tidak harus personel yang berasal dari dalam yayasan melainkan dapat diisi oleh orang dari luar yayasan (Pasal 28 ayat (30, Pasal 31 ayat (2), Pasal 40 ayat (3) Undang-undang yayasan.

5. Mengumumkan laporan keuangan Setiap tahunnya pengurus yayasan mempunyai kewajiban untuk membuat laporan tahunan yang berisi dua hal yaitu laporan keadaan dan kegiatan yayasan dan laporan keuangan. Laporan tersebut disahkan dalam rapat Pembina yayasan (Pasal 50 ayat (3) Undang-undang yayasan).

6. Pemeriksaan yayasan oleh pihak ketiga Yayasan yang diduga melakukan perbuatan yang kurang atau tidak baik, yaitu organnya: melakukan perbuatan melanggar hukum, lalai dalam menjalankan tugasnya, perbuatan merugikan yayasan atau pihak ketiga, atau perbuatan yang merugikan Negara, dapat dilakukan pemeriksaan berdasarkan penetapan pengadilan. Pengadilan mengeluarkan penetapan pemeriksaan atas dasar permintaan pihak ketiga, kecuali perbuatan yayasan yang merugikan Negara atas permintaan kejaksaan. 
Rumusan Pasal 11 ayat (1) Undang-undang No. 28 Tahun 2004 tentang Yayasan menguatkan bahwa yayasan untuk memperoleh status badan hukum harus membuat akta pendirian yayasan yang disahkan oleh Menteri Hukum dan Hak Asasi Manusia yang dibuat oleh notaris. Fungsi pengesahan dimaksudkan untuk keabsahan keberadaan badan hukum itu mempunyai kelayakan yaitu seberapa jauh atau tidaknya bertentangan dengan ketentuan perundang-undangan dengan yang ada, yayasan di bidang pendidikan merupakan syarat utamanya melakukan pendaftaran di muka notaris dan disahkannya di kementrian hukum dan HAM. Pendirian yayasan setelah berlakuknya Undang-undang No. 28 Tahun 2004 ini dianggap memberikan dampak positif mengingat pendirian badan hukum pendidikan sangat penting.

Mendirikan yayasan pendidikan harus memisahkan harta kekayaan pendirinya. Tercantum dalam Pasal 5 ayat (1) Undang-undang No. 28 tahun 2004 Tentang yayasan bahwa:

Kekayaan Yayasan baik berupa uang, barang, maupun kekayaan lain yang diperoleh Yayasan berdasarkan Undang-undang ini, dilarang dialihkan atau dibagikan secara langsung atau tidak langsung, baik dalam bentuk gaji, upah, maupun honorarium, atau bentuk lain yang dapat dinilai dengan uang kepada Pembina, Pengurus dan Pengawas. (2) Pengecualian atas ketentuan sebagaimana dimaksud pada ayat (1), dapat ditentukan dalam Anggaran Dasar Yayasan bahwa Pengurus menerima gaji, upah, atau honorarium, dalam hal Pengurus Yayasan:

a. bukan pendiri Yayasan dan tidak terafiliasi dengan Pendiri, Pembina, dan Pengawas;

b. melaksanakan kepengurusan Yayasan secara langsung dan penuh"

Pemisahan harta kekayaan merupakan perbuatan hukum yang sudah di atur dalam undang-undang, pemisahan kekayaan ini secara sukarela dari pendiri dalam melepaskan kekayaan. Kekayaan yang dilepaskan akan berubah statusnya sebagai badan hukum, dengan demikian tidak ada orang atau badan hukum yang berstatus sebagai pemilik atas suatu yayasan.

\section{a. Pengelolaan dan Pemeriksaan Terhadap Yayasan Pendidikan}

Setelah mengacu pada pendaftaran pendirian yayasan di bidang pendidikan Undang-undang No. 28 tahun 2004 juga mengatur Perubahan terhadap organ pengurus yayasan terletak pada Pasal 32 Ayat (2) Undang-Undang No. 28 Tahun 2004 menerangkan bahwa " pengurus yayasan dapat diangkat kembali setelah masa jabatan sebagaimana dimaksud pada ayat (1) ditentukan dalam anggaran dasar. Pengelolaan dan pemeriksaan terhadap yayasan agar terlaksana mencapai tujuan, memerlukan organ yang dapat bekerja dengan 
baik dan sesuai prosedur. Karena yayasan merupakan suatu badan hukum pendukung hak dan kewajiban.

Undang-undang No. 16 tahun 2001 menentukan tiga jenis organ yaitu: pembina, pengurus dan pengawas. Pembina adalah organ yayasan yang mempunyai kewenangan yang tidak diserahkan kepada pengurus dan pengawas oleh undang-undang atau anggaran dasar. Sedangkan pengurus adalah organ yayasan yang melaksanakan pengurusan yayasan, dan pengawas adalah organ yayasan yang bertugas melakukan pengawasan serta memberi nasihat kepada pengurus dalam menjalankan kegiatan yayasan.

Sebelum adanya perubahan organ yayasan pada Undang-undang No. 16 Tahun 2001, organ yayasan pendidikan tidak menegaskan atau mengatur masa jabatan pengurus dari yayasan. Perubahan tentang organ pengurus yayasan dibidang pendidikan ini memberikan dampak positif, dikarenakan jabatan suatu organ pengurus diberi masa kerja selama 5 tahun dan dapat digantikan setelah masa kerja selesai, sehingga meminimalisir penguasaan jabatan di suatu yayasan, masa jabatan bisa tetap diperpanjang seizin oleh pembina yayasan dan hasil pemilihan internal yayasan.

\section{Kesimpulan}

1. Persepsi dan pengetahuan masyarakat (pengurus yayasan) atas keberadaan Undangundang Yayasan belum berbanding lurus dengan pengetahuannya atas substansi yang dirubah. UU Nomor 28 Tahun 2004 Tentang Perubahan Atas UU Nomor 16 Tahun 2001 tentang yayasan menyatakan bahwa setiap yayasan adalah sebuah badan hukum yang mengikuti prosedur dan mekanisme yang sudah diatur dalam undangundang dimaksud. Salah satunya adalah mewajibkan setiap yayasan untuk mendaftar dan menyesuaikan anggaran dasarnya sekaligus mendapatkan pengesahan dari Kementerian Hukum dan HAM. Sehingga kapasitasnya dapat dianggap sebagai badan hukum dan sebagai salah satu bentuk pertanggung jawaban terhadap publik. Konsekuensinya adalah setiap yayasan pendidikan dan atau melalui notaris yang membuat akta pendiriannya harus menyesuaikan anggaran dasarnya sesuai dengan ketentuan UU Yayasan. Hal inilah tentunya yang harus dipahami oleh setiap satuan penyelengga pendidikan.

2. Undang-undang Nomor 28 Tahun 2004 Tentang Perubahan Atas Undang-undang Nomor 16 Tahun 2001 tentang Yayasan menyatakan bahwan setiap yayasan adalah sebuah badan hukum yang sudah barang tentu harus mengikuti prosedur dan mekanisme yang sudah diatur dalam undang-undang dimaksud. Salah satunya adalah mewajibkan setiap yayasan untuk mendaftar dan menyesuaikan anggaran dasarnya sekaligus mendapatkan pengesahan dari Kementerian Hukum dan HAM. 


\section{E. Saran}

Perlu adanya keterlibatan semua pemangku kepentingan yang terkait dengan Undang-undang Yayasan. Pemerintah atau swasta dapat menuangkan perubahan undang-undang dalam satu naskah, sehingga masyarakat dapat dengan mudah mempelajarinya. Dengan kata lain undang-undang yang mengalami perubahan mudah disosialisasikan.

\section{REFERENSI}

Ari Chatamarrajid Ais, 2006, Badan Hukum Yayasan Edisi Revisi, Bandung: Citra Aditya Bakti

Dita Badri, Pujiono, Kedudukan Yayasan Pasca Berlakunya Undang-undang No. 28 Tahun 2004 Tentang Perubahan Atas Undang-undang No. 16 Tahun 2001 Tentang Yayasan, 2016, Privat Law Volume 16 No.2 Desember 2016.

Taufik H. Simatupang, Kesadaran badan Hukum Yayasan Pendidikandi Indonesia (Persepsi dan Kesadaran Masyarakat), 2016, Jurnal Penelitian Hukum De Jure Volume 16 Nomor 3, September 2016.

Y Sogar Simamora, Karakteristik Pengelolaan dan Pemeriksaan Badan Hukum Yayasan di Indonesia, 2012, Jurnal Rechts Vinding Media Pembinaan Hukum Nasional Vol 1 No. 2 Agustus 2012

\section{Perundang-undangan}

Undang Undang Dasar 1945

Undang Undang Republik Indonesia No. 20 Tahun 2003 Tentang Sistem Pendidikan

Undang-Undang Nomor 16 Tahun 2001 Tentang Yayasan

Undang Undang Nomor 28 Tahun 2004 Tentang Perubahan Atas Undang Undang 16 Tahun 2001 Tentang Yayasan 